\title{
Two Roles of Mucin Sulfation
}

\author{
ムチン硫酸化の二つの役割
}

\begin{abstract}
Kawashima, Hiroto
Laboratory of Microbiology and Immunology, School of Pharmaceutical Sciences, University of Shizuoka, Shizuoka 422-8526, Japan, and PRESTO, Japan Science and Technology Agency, Kawaguchi 332-0012, Japan
\end{abstract}

FAX: 81-54-264-5715, E-mail:kawashih@u-shizuoka-ken.ac.jp

(Received on May 6, 2010, accepted on July 14, 2010)

Key Words: mucin, sulfotransferase, O-glycan, lymphocyte homing, L-selectin, high endothelial venule, Muc2

\begin{abstract}
Recent studies using gene-targeted mice have revealed various physiological functions of sulfated glycans. Studies using gene-targeted mice deficient in two sulfotransferases, $N$-acetylglucosamine-6- $O$-sulfotransferase (GlcNAc6ST)-1 and GlcNAc6ST-2, showed that these sulfotransferases catalyze sulfation of mucin-like glycoproteins expressed on high endothelial venules (HEVs) in lymph nodes, and play critical roles in lymphocyte homing and immune surveillance. More recent studies using GlcNAc6ST-2-deficeint mice revealed that GlcNAc6ST-2 is expressed not only in lymph node HEVs but also in the colonic epithelial cells in mice, and has protective function in experimental colitis in mice by catalyzing sulfation of the colonic mucins. In this review, the two distinct functions of sulfation of mucins or mucin-like glycoproteins by sulfotransferases in lymph nodes and colon will be discussed.
\end{abstract}

要 約

近年、遺伝子ターゲッティングマウスを用いた研究によ り、硫酸化糖鎖の様々な生理機能が明らかになってきた。二 つの硫酸基転移酵素 $N$ - アセチルグルコサミン 6-O- スルホト ランスフェラーゼ (GlcNAc6ST)-1 抄よびGlcNAc6ST-2 を欠損 する遺伝子ターゲッティングマウスを用いた解析により、そ れらの硫酸基転移酵素がリンパ節の高内皮細静脈 (HEV) に発 現するムチン様糖タンパク質の硫酸化を介してリンパ球ホー ミングおよび免疫監視において必須の機能を発揮することが 示されている。さらに最近の GlcNAc6ST-2 欠損マウスを用い た研究により、GlcNAc6ST-2 がマウスにおいてリンパ節 HEV のみではなく大腸上皮細胞にも発現し、大腸ムチンの硫酸化 を介して実験的大腸炎に対する防御機能を果たすことが示さ れている。本稿では、リンパ節㧍よび大腸に㧍けるムチンあ るいはムチン様糖タンパク質の硫酸化の二つの生理的意義に ついて論じる。

\section{A. Introduction}

The addition of sulfate groups to carbohydrate chains is catalyzed by sulfotransferases, which transfer a sulfate group from the sulfate donor, 3'-phosphoadenosine 5'-phosphosulfate (PAPS), to a specific position on the acceptor oligosaccharide. $\mathrm{N}$-acetylglucosamine-6- $O$-sulfotransferases (GlcNAc6STs) catalyze the 6-O-sulfation of $N$-acetylglucosamine (GlcNAc) on the acceptor oligosaccharide. So far, five GlcNAc6STs in humans and four in mice have been identified $(1,2)$.

Table I summarizes GlcNAc6STs in mice. One of the GlcNAc6STs, GlcNAc6ST-2 (also called HEC-GlcNAc6ST or L-selectin ligand sulfotransferase (LSST)) has been known to be specifically expressed in high endothelial venules (HEVs) $(3,4)$, where L-selectin-mediated lymphocyte recruitment to lymph nodes primarily occurs. L-selectin is a C-type lectin on the surface of lymphocytes which specifically binds to sulfated glycans on HEVs (5). Another member of this
A. はじめに

糖鎖への硫酸基の付加は、硫酸基供与体 3’ - ホスホアデ ニリル硫酸 (PAPS) からアクセプター糖鎖の特定の部位に硫酸 基を転移する硫酸基転移酵素により触媒される。 $N$ - アセチル グルコサミン 6-O-スルホトランスフェラーゼ(GlcNAc6ST) は、 アクセプター糖鎖の $N$ - アセチルグルコサミン (GlcNAc) の 6 位に硫酸基を転移する。現在までに、ヒトで 5 種、マウスで 4 種の GlcNAc6ST が同定されている $(1,2) 。$

マウスGlcNAc6ST に関して表Iにまとめる。そのうち の一つである GlcNAc6ST-2 (別名 HEC-GlcNAc6ST または L-selectin ligand sulfotransferase (LSST)) は、L- セレクチン 依存性のリンパ節へのリンパ球浸潤を媒介する高内皮細静脈 (HEV) に発現することが知られてきた $(3 ， 4)$ 。 L- セレクチンは リンパ球表面に発現するC 型レクチンであり、HEV 上の硫 酸化糖鎖と特異的に結合する (5)。この硫酸基転移酵素ファミ 
Table I. Mouse $N$-acetylglucosamine-6- $O$-sulfotransferases.

\begin{tabular}{|c|c|c|c|c|}
\hline Name & Other names & $\begin{array}{l}\text { cDNA } \\
\text { accession } \\
\text { number }\end{array}$ & $\begin{array}{l}\text { Tissue } \\
\text { distribution }\end{array}$ & Function etc. \\
\hline GlcNAc6ST-1 & $\begin{array}{l}\text { GlcNAc6ST } \\
\text { CHST (carbohydrate } \\
\text { sulfotransferase)-2 } \\
\text { GST (galactose/N- } \\
\text { acetylgalactosamine } / N \text { - } \\
\text { acetylglucosamine 6-O- } \\
\text { sulfotransferase)-2 }\end{array}$ & AB011451 & $\begin{array}{l}\text { Various } \\
\text { tissues } \\
\text { including } \\
\text { HEV }\end{array}$ & $\begin{array}{l}\text { In GlcNAc6ST-1-deficient mice, } \\
\text { lymphocyte homing to PLN was } \\
\text { reduced by } 20 \%(6) \text {. In these mice, } \\
\text { the binding of MECA- } 79 \text { to the } \\
\text { HEV of PP disappeared. }\end{array}$ \\
\hline GlcNAc6ST-2 & $\begin{array}{l}\text { LSST (L-selectin ligand } \\
\text { sulfotransferase) } \\
\text { HEC-GlcNAc6ST (high } \\
\text { endothelial cell } N \text { - } \\
\text { acetylglucosamine 6- } \\
\text { sulfotransferase) } \\
\text { CHST-4 } \\
\text { GST-3 }\end{array}$ & AF109155 & $\begin{array}{l}\text { HEV } \\
\text { colon }\end{array}$ & $\begin{array}{l}\text { In GlcNAc6ST-2-deficient mice, } \\
\text { lymphocyte homing to PLN was } \\
50 \% \text { reduced }(16,17) . \text { In these } \\
\text { mice, luminal staining of PLN } \\
\text { HEV with MECA-79 disappeared. }\end{array}$ \\
\hline GlcNAc6ST-3 & $\begin{array}{l}\text { I-GlcNAc6ST (intestinal } \\
\mathrm{N} \text {-acetylglucosamine 6- } \\
\mathrm{O} \text {-sulfotransferase) } \\
\text { CHST-5 } \\
\text { GST-4 }\end{array}$ & AF176840 & cornea & $\begin{array}{l}\text { In mice, only I (Intestinal)- } \\
\text { GlcNAc6ST (GlcNAc6ST-3, } \\
\text { CHST-5) is present. In humans, I- } \\
\text { GlcNAc6ST (GlcNAc6ST-3, } \\
\text { CHST-5, and GST-4 } \alpha \text { ) and C } \\
\text { (Corneal)-GlcNAc6ST } \\
\text { (GlcNAc6ST-5, CHST-6, and GST- } \\
4 \beta \text { ) are present because of gene } \\
\text { duplication (38). }\end{array}$ \\
\hline GlcNAc6ST-4 & $\begin{array}{l}\text { C6ST (chondroitin 6- } \\
\text { sulfotransferase)-2 } \\
\text { CHST-7 } \\
\text { GST-5 }\end{array}$ & AF280089 & $\begin{array}{l}\text { Various } \\
\text { tissues } \\
\text { including } \\
\text { HEV }\end{array}$ & $\begin{array}{l}\text { GlcNAc6ST-4 transfers sulfate to } \\
\text { recombinant GlyCAM-1-IgG (39). } \\
\text { In vivo function of GlcNAc6ST-4 is } \\
\text { unknown. }\end{array}$ \\
\hline
\end{tabular}

sulfotransferase family, GlcNAc6ST-1, is also expressed in HEVs (6). Previously, our group (7) and others (8) generated gene-targeted mice deficient in both GlcNAc6ST-1 and GlcNAc6ST-2 to determine whether GlcNAc6ST-1 and GlcNAc6ST-2 had complementary roles in L-selectin ligand biosysnthesis in HEV as described in detail in the following sections.

During the course of generating a transgenic mouse line expressing Cre recombinase under the transcriptional regulatory elements for the gene encoding GlcNAc6ST-2, we found that GlcNAc6ST-2 is strongly expressed not only in lymph nodes but also in the colon in mice (9). Further analysis indicated that the cells expressing GlcNAc6ST-2 in the mouse colon were reactive with an antibody against Muc2, a major intestinal mucin produced by the goblet cells in the colon, suggesting that GlcNAc6ST-2 catalyzes the sulfation of not only mucin-like glycoproteins which serve as L-selectin ligands in HEVs but also colonic mucins in mice. In this review, functional significance of sulfation of mucin or mucin-
リーのもう一つのメンバーである GlcNAc6ST-1 も HEV に発 現する (6)。以前我々のグループ (7) 䇽よび他のグループ (8) は、 GlcNAc6ST-1 と GlcNAc6ST-2 が HEV に扔けるL- セレクチ ンリガンドの生合成に相補的な機能を果たすかどうかを明ら かにするために、GlcNAc6ST-1 およびGlcNAc6ST-2 の両者を 欠損する遺伝子ターゲッティングマウスを作製した。これに ついては後のセクションで詳しく述べる。

GlcNAc6ST-2 をコードする遺伝子の転写制御領域の支配 下にCreリコンビナーゼを発現するトランスジェニックマウ スを作製する過程で、我々はGlcNAc6ST-2 がマウスに执い てリンパ節のみではなく大腸にも強く発現することを見いだ した (9)。さらに解析を進めたところ、マウス大腸において GlcNAc6ST-2 を発現する細胞は、大腸の杯細胞が産生する腸 管に打ける主要なムチンである Muc2 に対する抗体に反応性 を示すことがわかった。このことから、GlcNAc6ST-2 は L- セ レクチンリガンドとして働くムチン様糖タンパク質の硫酸化 のみでなく、マウス大腸ムチンの硫酸化も媒介する可能性が 考えられた。本稿では、リンパ節 HEV および大腸に掠ける 
like glycoproteins by GlcNAc6STs in lymph node HEV and colon will be discussed.

\section{B. Homing Receptor L-Selectin}

Lymphocytes are generated in primary lymphoid organs, such as the bone marrow and thymus, and migrate to the lymph nodes, Peyer's patches, and spleen, known as secondary lymphoid organs, where foreign antigens accumulate and immune responses primarily occur. Lymphocytes that migrate to the lymph nodes and Peyer's patches emigrate through the efferent lymphatics to the lymph, unless they encounter their cognate antigens. Lymphocytes that emigrate to the lymph return to the bloodstream through the thoracic duct, through which lymph fluid drains into the blood. Lymphocytes that return to the blood migrate again into the secondary lymphoid organs. This circulatory process is called lymphocyte recirculation or lymphocyte homing. The homing of lymphocytes into secondary lymphoid organs through the blood and lymph circulation raises the likelihood that lymphocytes will encounter antigens. In other words, lymphocyte homing is important for the immune system to recognize foreign antigens efficiently.

The homing receptor L-selectin (LECAM-1, CD62L, LAM-1) was first identified as an antigen recognized by the monoclonal antibody (mAb) MEL-14, which blocks the binding of lymphocytes to $\mathrm{HEV}$ in vitro and in vivo (10). L-selectin is an adhesion molecule that recognizes carbohydrates through a lectin-like domain in its N-terminus,
GlcNAc6ST によるムチンまたはムチン様糖タンパク質の硫酸 化の機能的意義について論じる。

B. ホーミングレセプター・L- セレクチン

骨髄や胸腺などの一次リンパ組織で産生されたリンパ球 は、外来性の抗原が濃縮され免疫応答が起こる場であるリン パ節、パイエル板、脾臓などの二次リンパ組織に血管系を介 して移住する。リンパ節、パイエル板に移住したリンパ球は、 対応抗原に出会わない限りは、輸出リンパ管からリンパ液中 に移行する。リンパ液中に遊出したリンパ球は、リンパ液が 血液と合流する胸管を介して再び血液中に戻る。そして再び 血管系を介して、二次リンパ組織に向かうという現象を繰り 返す。この循環過程は、リンパ球再循環現象 (lymphocyte recirculation) またはリンパ球ホーミング現象 (lymphocyte homing) と呼ばれる。抗原感作を受けていないリンパ球が恒常的 に血管系・リンパ系を介して二次リンパ組織間を循環するこ とにより、リンパ球が抗原と出会う確率が高まる。すなわち、 リンパ球ホーミングは二次リンパ組織においてリンパ球が効 率良く抗原と出会うために重要である。

L- セレクチン (LECAM-1、CD62L、LAM-1) は、in vitro およびin ViVoでリンパ球と末梢リンパ節 HEV との結合を特 異的に阻害するモノクローナル抗体 MEL-14の認識する抗原 として同定され (10)、ホーミングレセプターとも呼ばれてい る。L- セレクチンは N- 末端側のレクチンドメインを介して糖 鎖を認識する細胞接着分子で、リンパ球と HEV の相互作用に おける初期の tethering とローリングを媒介する。L- セレクチ

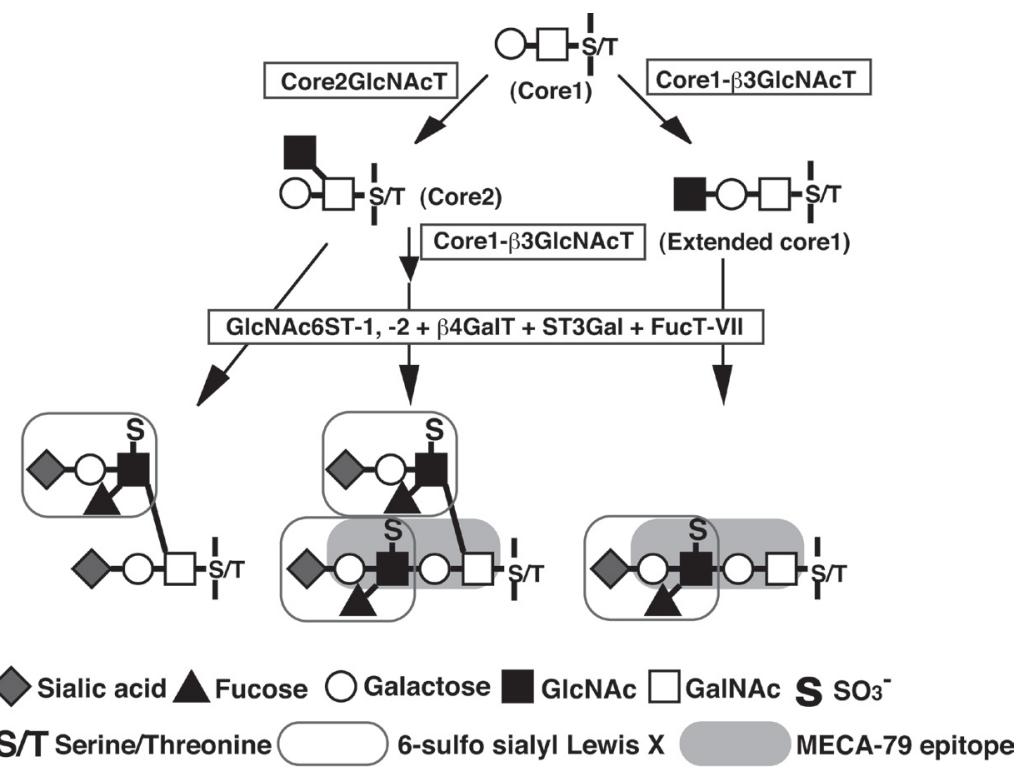

Fig.1. Biosynthesis of the L-selectin ligand $\boldsymbol{O}$-glycans. Core 2 branched $\boldsymbol{O}$-glycan (left), extended core 1 structure (right), and biantennary $O$-glycan containing both core 2 branch and extended core 1 structures (middle) modified with 6-sulfo sialyl Lewis $\mathrm{X}$ are synthesized in HEV by the sequential addition of monosaccharides and sulfate. The extended core 1 structure modified with GlcNAc-6- $O$-sulfate (shaded in gray) is recognized by the MECA-79 antibody. Core2GlcNAcT, Core $2 \beta 1,6-N$-acetylglucosaminyltransferase; Core1- $\beta 3$ GlcNAcT, Core 1 extension $\beta 1,3-N$-acetylglucosaminyltransferase, GlcNAc6ST-1, -2, $N$-acetylglucosamine-6- $O$-sulfotransferase-1, -2 ; $\beta 4 \mathrm{GalT}, \beta 1,4$-galactosyltransferase; ST3Gal, $\alpha 2,3$-sialyltransferase; FucT-VII, fucosyltransferase-VII. 
through which it mediates the initial tethering and rolling interaction of lymphocytes on the surface of HEV. L-selectin is localized to the tips of microvilli (11), which is advantageous for the initial tethering to HEV-borne carbohydrate ligands. To date, several kinds of glycoprotein ligands for L-selectin have been identified (5).

\section{Ligands for L-Selectin}

Studies of the ligands for L-selectin that are expressed on the lymph node HEV have identified various mucinlike glycoproteins, such as GlyCAM-1, CD34, podocalyxinlike protein, and Sgp200 (5). The binding of these mucinlike glycoprotein ligands to L-selectin is dependent on their decoration with a specific carbohydrate structure known as 6-sulfo sialyl Lewis X (Sialic acid $\alpha 2-3$ Gal $\beta 1-4[$ Fuc $\alpha 1$ 3(sulfo-6)]GlcNAc $\beta 1-R$ ), which contains sialic acid, fucose, and sulfate (Fig. 1). The 6-sulfo sialyl Lewis X structure is present in either the core 2 or extended core 1 branch, or both, of the L-selectin ligand $O$-glycans. MECA-79 antibody, which is widely used to detect HEV in lymph nodes or HEVlike vessels at the sites of chronic inflammation, recognizes $O$-glycans containing 6-sulfo GlcNAc in the extended core 1 structure (12).

Earlier studies by Dr. Rosen's group showed that sialic acid is critical for the interaction of HEV ligands with lymphocytes (13). Studies using double-null mice deficient in fucosyltransferase IV and VII revealed that the fucosylation of HEV ligands is also critical for their interaction with L-selectin (14). In vitro biochemical studies showed that the sulfation of L-selectin ligands is also important for their interaction with L-selectin, since GlyCAM-1 biosynthesized in the presence of sodium chlorate, which inhibits biosynthesis of PAPS, the high-energy donor of sulfate, did not interact with L-selectin (15).

\section{Roles of L-Selectin Ligand Sulfation In Vivo}

To determine the sulfation requirement of the L-selectin ligands in vivo, mice deficient in GlcNAc6ST-2 were generated $(16,17)$. In the GlcNAc6ST-2 knockout mice, binding of the MECA-79 antibody to lymph node HEV was significantly diminished, except for binding observed in the abluminal lining of the HEV, suggesting that GlcNAc6ST-2 is a major but not the sole GlcNAc6ST involved in GlcNAc-6$O$-sulfation of mucin-like glycoproteins in HEV.

In mice, four members of the GlcNAc6ST family have been reported (Table I). One of these, GlcNAc6ST-1, is widely expressed in various tissues, including lymph node HEV (6). Our group (7) and others (8) therefore crossbred GlcNAc6ST-2-deficient mice with GlcNAc6ST-1-deficient mice to determine whether GlcNAc6ST-1 and GlcNAc6ST-2 had complementary roles in L-selectin ligand biosynthesis.
ンはリンパ球表面の微絨毛の先端に存在しており、リンパ球 が HEV との接着を開始する初期の tethering にはこの局在が 重要であることが示されている $(11)$ 。現在までに、リンパ節 $\mathrm{HEV}$ 上に発現する糖タンパク質性の L- セレクチン・リガン ドが数種類同定されている (5)。

C. L- セレクチンのリガンド

リンパ節 HEV に発現する L- セレクチンのリガンドと して、GlyCAM-1、CD34、ポドカリキシン様タンパク質、 Sgp200 などの様々なムチン様糖タンパク質が同定されてい る (5)。これらのムチン様糖タンパク質リガンドが L- セレク チンと結合するためには、シアル酸、フコースおよび硫酸 基をもつ 6- スルホシアリルルイス X (Sialic acid $a$ 2-3Gal $\beta$ 1$4[$ Fuc $\alpha$ 1-3(sulfo-6)]GlcNAc $\beta$ 1-R) と呼ばれる特殊な糖鎖構造 による修飾を受ける必要がある(図 1)。6-スルホシアリルル イス X 構造は L- セレクチンリガンドの $O$ - 型糖鎖のコア 2 分 岐、伸長型コア 1 およびその双方に付加する。また、リンパ 節の HEV および慢性炎症巣の HEV 様血管を検出するために 広く用いられてきたMECA-79 抗体は、6 位が硫酸化された GlcNAc 残基を含む伸長型コア 1 構造を認識する (12)。

Rosen 博士のグループの初期の研究により HEV における リガンドと L- セレクチンの結合にはシアル酸が必須であるこ とが示されている (13)。フコシルトランスフェラーゼIV およ びVII 二重遺伝子欠損マウスを用いた結果により、HEVリガ ンドのフコースによる修飾も L- セレクチンとの相互作用に必 須であることが示されている(14)。また、in vitroにおける生 化学的な研究により L- セレクチンリガンドの硫酸化も L- セ レクチンとの相互作用に重要であることが示されている。す なわち、硫酸基の高エネルギードナーであるPAPSの生合 成を阻害する塩素酸ナトリウムの存在下で生合成された GlyCAM-1 は L- セレクチンと相互作用しない (15)。

\section{L- セレクチンリガンドの硫酸化の in vivo における役割}

L- セレクチンリガンドの in vivo における硫酸基の依存性 を明らかにするために、GlcNAc6ST-2 欠損マウスが作製され た (16,17)。GlcNAc6ST-2 欠損マウスにおいてはMECA-79 抗 体とリンパ節 HEV の結合は HEV の基底膜側の染色以外は顕 著に低下した。この結果は、GlcNAc6ST-2 はHEV における ムチン様糖タンパク質の硫酸化を担う主要な GlcNAc6ST で あるが唯一のものではないことを示唆している。

マウスにおいてはGlcNAc6ST ファミリーに属する酵素 として、4 種類が報告されている(表 1$)$ 。そのうちの一つで ある GlcNAc6ST-1 はリンパ節を含む様々な組織に広汎に発 現している (6)。それ故に、我々のグループ (7) と他のグルー プ (8) は、GlcNAc6ST-2 欠損マウスと GlcNAc6ST-1 欠損マ ウスを掛け合わせ、L-セレクチンリガンドの生合成において GlcNAc6ST-1 と GlcNAc6ST-2 が相補的な機能を果たすかど 
A

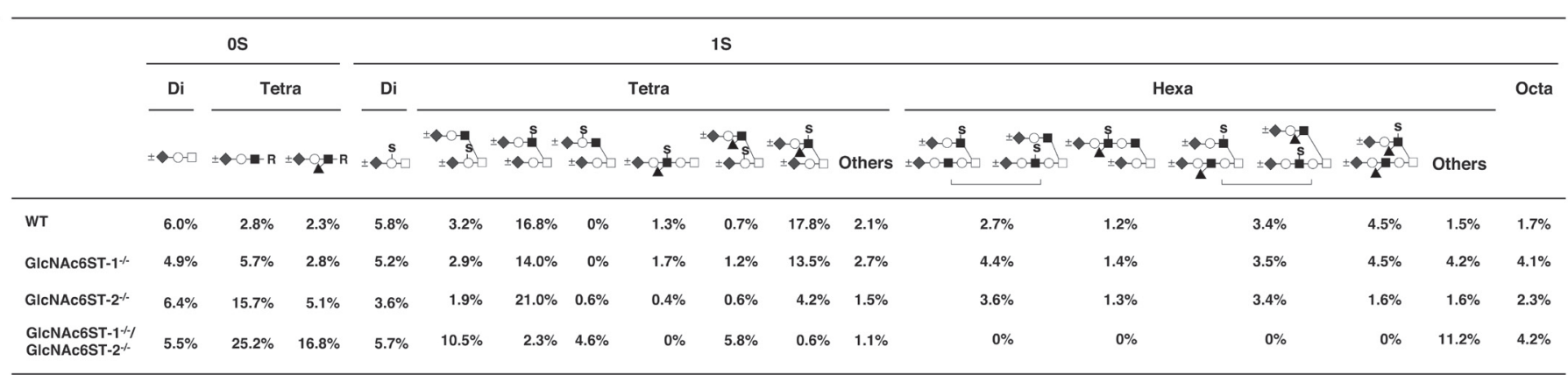

\begin{tabular}{|c|c|c|c|c|c|c|c|c|c|c|c|}
\hline & \multicolumn{7}{|c|}{$2 S$} & \multirow{3}{*}{ Octa } & \multirow[t]{3}{*}{$3 S$} & \multirow[t]{3}{*}{$4 \mathrm{~S}$} & \multirow[t]{3}{*}{$5 S$} \\
\hline & \multicolumn{2}{|c|}{ Tetra } & \multicolumn{5}{|c|}{ Hexa } & & & & \\
\hline & 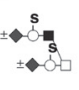 & & $s s$ & & 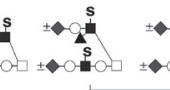 & & Others & & & & \\
\hline WT & $0.8 \%$ & $7.9 \%$ & $2.0 \%$ & $0.4 \%$ & $1.9 \%$ & $1.3 \%$ & $0.8 \%$ & $1.0 \%$ & $8.4 \%$ & $1.8 \%$ & $0.3 \%$ \\
\hline GlcNAc6ST-1\% & $1.3 \%$ & $4.6 \%$ & $1.0 \%$ & $1.0 \%$ & $1.5 \%$ & $0.9 \%$ & $3.3 \%$ & $1.7 \%$ & $6.6 \%$ & $1.4 \%$ & $0.1 \%$ \\
\hline GICNAC6ST-2 ${ }^{-/}$ & $1.6 \%$ & $6.3 \%$ & $0.6 \%$ & $2.0 \%$ & $1.1 \%$ & $0.3 \%$ & $0.8 \%$ & $1.3 \%$ & $9.1 \%$ & $2.0 \%$ & $0.2 \%$ \\
\hline 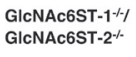 & $3.6 \%$ & $0.5 \%$ & $0 \%$ & $0 \%$ & $0 \%$ & $0 \%$ & $1.4 \%$ & $0.3 \%$ & $0.9 \%$ & $0 \%$ & $0 \%$ \\
\hline
\end{tabular}

Total O-glycan $=100 \%$

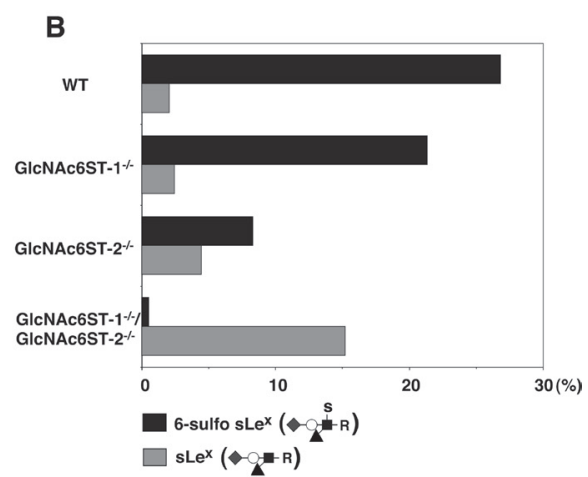

Fig. 2. Structures of $\boldsymbol{O}$-glycans attached to GlyCAM-1. (A) Structures of unsulfated (0S), monosulfated (1S), and disulfated (2S) $O$-glycans on a disaccharide core (Di), tetrasaccharide core (Tetra), or hexasaccharide core (Hexa) structure attached to GlyCAM-1 from different mouse lines. (B) The percentage of $O$-glycans attached to GlyCAM-1 containing 6-sulfo sialyl Lewis X (6-sulfo sLe ${ }^{\mathrm{x}}$ ) and unsulfated sialyl Lewis X $\left(\mathrm{sLe}^{\mathrm{x}}\right)$. Total $O$-glycans attached to GlyCAM-1 $=100 \%$.

Immunofluorescence studies revealed that the binding of the MECA-79 antibody to the lymph node HEV of the doubledeficient mice was completely abrogated, indicating that GlcNAc-6-O-sulfation in the extended core 1 branch of $O$-glycans in HEV was absent in the double-deficient mice. While GlcNAc6ST-1 and GlcNAc6ST-2 single-deficient mice showed an approximately $20 \%$ and $50 \%$ reduction in lymphocyte homing, respectively, the double-deficient mice showed an approximately $75 \%$ reduction in lymphocyte homing. The contact hypersensitivity (CHS) responses using a hapten, 2,4-dinitrofluorobenzene (DNFB), were also significantly diminished in the double-deficient mice, due to a reduction in lymphocyte trafficking to the draining lymph nodes. These results demonstrate the essential role of GlcNAc6ST-1 and GlcNAc6ST-2 in L-selectin ligand biosynthesis in HEV and their importance in immune surveillance.

We then carried out a detailed carbohydrate structural analysis of GlyCAM-1, a major mucin-like glycoprotein in HEV (7). Lymph nodes from wild-type and knockout mice were radiolabeled with $\left[{ }^{3} \mathrm{H}\right]$-galactose in organ culture, and then the $O$-glycans on GlyCAM-1 were released by $\beta$-elimination and subjected to structural analysis. As shown in Fig. 2A, only a very small amount of oligosaccharide containing GlcNAc-6-O-sulfate was detected in double-
うかを解析した。免疫蛍光染色の結果、ダブルノックアウト マウスに㧍いてはMECA-79 抗体とリンパ節 HEV の結合は 完全に消失した。この結果は、ダブルノックアウトマウスに おいて、伸長型コア 1 構造の GlcNAcの 6 位硫酸化は存在し ないことを示している。GlcNAc6ST-1、GlcNAc6ST-2 単独欠 損マウスはそれぞれ、末梢リンパ節へのリンパ球ホーミング が 20\% 扮よび50\% 減少したが、ダブルノックアウトマウスで は約 75\% リンパ球ホーミングが減少した。所属リンパ節への リンパ球ホーミングの減少により、ダブルノックアウトマウ スに扮いてはハプテンである 2,4- ジニトロフルオロベンゼン (DNFB) を用いた接触性皮膚炎の反応も有意に低下した。以上 の結果より、GlcNAc6ST-1 と GlcNAc6ST-2 が HEV に扔ける L- セレクチンリガンドの硫酸化抢よび免疫監視に扔いて必須 の役割を果たすことが明らかとなった。

次に我々は、HEV の主要なムチン様糖タンパク質である GlyCAM-1 の糖鎖構造解析を行った (7)。野生型マウスおよび ノックアウトマウスのリンパ節を $\left[{ }^{3} \mathrm{H}\right]-$ ガラクトースを用いた 組織培養により標識し、GlyCAM-1の O - 型糖鎖を $\beta$ - 脱離に より遊離させ、糖鎖解析に用いた。図 $2 \mathrm{~A}$ に示すように、ダブ ルノックアウトマウスに拈いては非常に少量の GlcNAc-6 硫酸 を含む糖鎖のみが認められた ( 図の左から 6 番目および 10 番 目の構造 $) 。$ 一方、ガラクトース -6 硫酸を含む糖鎖はダブルノッ 
knockout mice (see 6th and 10th structures from the left). Conversely, the relative amount of sulfated oligosaccharides containing galactose-6- $O$-sulfate significantly increased in double-knockout mice. As summarized in Fig. 2B, the 6-sulfo sialyl Lewis X structure was almost completely abrogated, whereas unsulfated sialyl Lewis $\mathrm{X}$ was overexpressed in the double-deficient mice. Thus, the most likely candidate for supporting residual $25 \%$ lymphocyte trafficking to PLN observed in double-knockouts is the unsulfated sialyl Lewis $\mathrm{X}$ structure known to interact with L-selectin. Consistent with this hypothesis, pre-injection of the fucose- and sialic acid-specific lectins, Aleuria aurantia agglutinin (AAA) and Maackia amurensis agglutinin (MAA), respectively, significantly inhibited lymphocyte homing to PLN in the GlcNAc6ST-1 and -2 double-knockouts (7), confirming that both fucose and sialic acid, constituents of sialyl Lewis X, are essential for residual lymphocyte homing observed in these mice.

To determine which GlcNAc6STs are expressed in HEV, we performed RT-PCR analysis using total RNA from HEV cells of wild-type mice, prepared by magnetic activated cell sorter (MACS) using the MECA-79 antibody (7). In addition to GlcNAc6ST-1 and -2, GlcNAc6ST-4 was detected, whereas GlcNAc6ST-3 expression was not detectable. As shown in Fig. 3, all of these mouse GlcNAc6STs efficiently transferred sulfate to core 2 branched $O$-glycans. On the other hand, only GlcNAc6ST-2 and -3 efficiently transferred sulfate to extended core $1 O$-glycans, which resulted in the generation of a large amount of MECA-79 epitope. GlcNAc6ST-4 did not synthesize detectable amounts of MECA-79 epitope, consistent with the finding that the MECA-79 epitope was

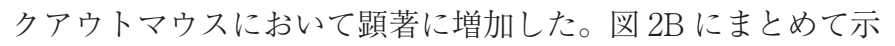
すように、ダブルノックアウトマウスに扮いて 6-スルホシア リルルイス X はほぼ完全に消失するのに対して、硫酸化され ていないシアリルルイスXが過剩に発現していた。このこと から、ダブルノックアウトマウスに打いて認められた残りの 25\%の PLNへのリンパ球ホーミングには、L- セレクチン結合 性を持つことが知られている硫酸化されていないシアリルル イスXが関与する可能性が高いと考元られる。この仮説と一 致して、フコース特異的なヒイロチャワンタケレクチン (AAA) あるいはシアル酸特異的なイヌエンジュレクチン $(\mathrm{MAA})$ をあ らかじめ静脈内投与しておくと GlcNAc6ST-1, -2 ダブルノック アウトマウスに抢ける PLNへのリンパ球ホーミングが顕著に 抑制された (7)。このことから、シアリルルイス X を構成する 糖残基であるフコース拉よびシアル酸がダブルノックアウト マウスに扔ける残存するホーミングに関与することが確認さ れた。

どの GlcNAc6ST が HEV に発現するのかを調べるために、 MECA-79 抗体を用いて細胞磁気分離法 (MACS)により野生型 マウスの HEV 細胞を精製し、その全 RNA を用いて RT-PCR による解析を行った (7)。その結果、GlcNAc6ST-1, -2 のみでは なく、GlcNAc6ST-4の発現も認められた。一方、GlcNAc6ST-3の 発現は検出されなかった。眓 3 に示すようにこれらのマウス GlcNAc6ST はいずれもコア 2 分岐 $O$ - 型糖鎖に効率よく硫酸 基を転移した。一方、GlcNAc6ST-2 と GlcNAc6ST-3 のみが効 率よく伸長型コア 1 糖鎖に硫酸基を転移し、MECA-79 エピトー プを大量に産生した。GlcNAc6ST-4による MECA-79 エピトー プの産生は検出されなかった。この結果は、GlcNAc6ST-1 およびGlcNAc6ST-2 のダブルノックアウトマウスにおいて

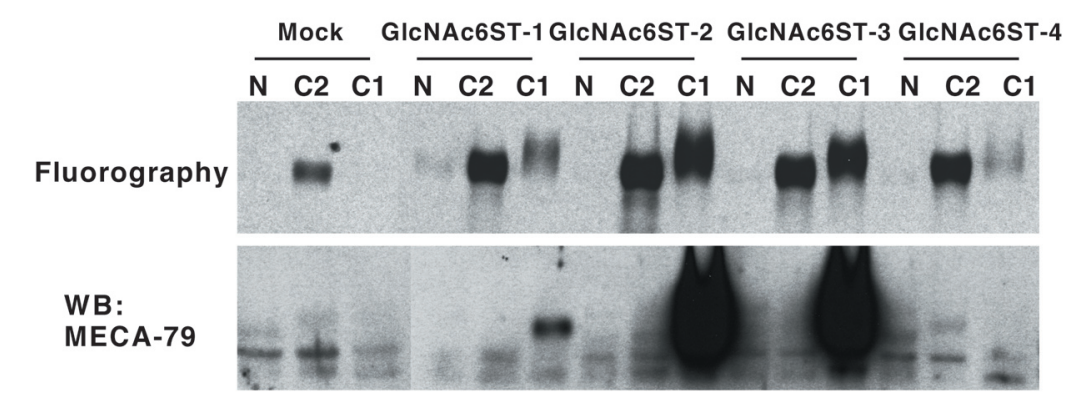

\begin{tabular}{lcccc}
\hline & GIcNAc6ST-1 & GIcNAc6ST-2 & GIcNAc6ST-3 & GIcNAc6ST-4 \\
\hline $\begin{array}{l}\text { Substrate } \\
\quad\end{array}$ & +++ & +++ & +++ & +++ \\
$\begin{array}{l}\text { Extended core } 1 \\
\text { MECA-79 epitope }\end{array}$ & + & +++ & +++ & \pm \\
\begin{tabular}{l} 
synthesis \\
\hline
\end{tabular} & + & +++ & +++ & - \\
\hline
\end{tabular}

Fig. 3. Substrate specificity of mouse GIcNAc6STs. Lec2 cells were transiently transfected with expression vectors encoding GlyCAM-1-IgG, with or without (N) Core2GlcNAcT-I (C2) or Core1-33GlcNAcT (C1), together with GlcNAc6ST-1 to -4 , and metabolically labeled with $\left[{ }^{35} \mathrm{~S}_{-}-\mathrm{Na}_{2} \mathrm{SO}_{4}\right.$. GlyCAM-1-IgG was purified with protein A-Sepharose and subjected to fluorography and Western blotting using the MECA-79 antibody. 
abrogated in the GlcNAc6ST-1 and -2 double-deficient mice. The small amount of core 2 branched $O$-glycans containing GlcNAc-6- $O$-sulfate identified in the double-deficient mice was probably synthesized by GlcNAc6ST-4. Recently, it was reported that not only $O$-glycans but also $N$-glycans attached to the L-selectin ligand mucin-like glycoproteins play critical roles in L-selectin-mediated lymphocyte homing and recruitment (18). It is plausible that GlcNAc6ST-1, -2 , and -4 that are expressed in HEV are also involved in the sulfation of $\mathrm{N}$-glycans attached to those mucin-like glycoproteins.

\section{E. Expression of GIcNAc6ST-2 in the Mouse Colon}

During the course of generating a transgenic mouse line expressing Cre recombinase under the transcriptional regulatory elements for the gene encoding GlcNAc6ST-2 using recombinat bacterial artificial chromosome (BAC) (Fig. 4A), we found that Cre recombinase expression which represents intrinsic GlcNAc6ST-2 expression is clearly detected not only in lymph node HEVs but also in the colon (Fig. 4B) (9). The expression of GlcNAc6ST-2 in the mouse colon was also confirmed by RT-PCR analysis (9).

We thus sought to determine whether GlcNAc6ST-2 is involved in the sulfation of colonic mucins, using GlcNAc6ST-2-deficient mice (19). To assess the mucin sulfation, serial sections were stained with Alcian blue and an antibody against Muc2, a major intestinal mucin (Fig. 5). The Alcian blue staining was performed at $\mathrm{pH} 1.0$, because Alcian blue selectively binds to sulfated carbohydrates under
MACA-79 エピトープが完全に消失したことと一致する。ダブ ルノックアウトマウスで検出されたごく少量の GlcNAc-6 硫酸 を含むコア 2 分岐 $O$ - 型糖鎖は、扮そらくGlcNAc6ST-4によ り合成されたと考えられる。最近、L-セレクチンリガンドと して働くムチン様糖タンパク質の $O$ - 型糖鎖のみでなく $N$ - 型 糖鎖も、L- セレクチン依存性のリンパ球ホーミングおよびリ ンパ球動員に必須の機能を果たすことが報告されている (18)。 おそらくは、HEV に発現する GlcNAc6ST-1，-2 抒よび-4がこ れらのムチン様糖タンパク質に付加する $\mathrm{N}$ - 型糖鎖の硫酸化に も関与するものと考えられる。

\section{E. マウス大腸における GlcNAc6ST-2 の発現}

我々は、GlcNAc6ST-2 をコードする遺伝子の転写制御領 域の下流にCreリコンビナーゼ遺伝子を挿入した組換え型細 菌人工染色体 (BAC, 図 4A) を用いてトランスジェニックマウ スを樹立する過程で、本来の GlcNAc6ST-2 の発現を反映する Cre リコンビナーゼの発現が、リンパ節 HEV のみでなく、大 腸にもはっきりと認められることを見いだした (図 4B) (9)。ま た、マウス大腸に扔いて GlcNAc6ST-2 が発現することをRTPCR により確認した (9)。

そこで次に我々は GlcNAc6ST-2 が大腸ムチンの硫酸化に 関与するか否かを GlcNAc6ST-2 欠損マウスを用いて解析した (19)。ムチンの硫酸化を調べるために、連続切片をアルシアン ブルーおよび腸管内の主要なムチンである Muc2 に対する抗 体を用いて染色を行った(図 5)。アルシアンブルーは pH1.0の 条件下で硫酸化糖鎖に選択的に結合するため、染色はその条

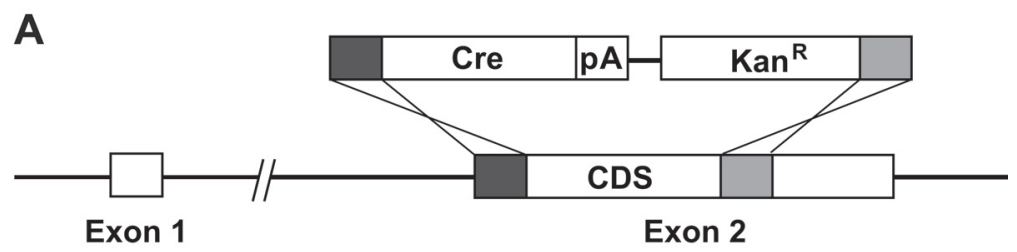

B

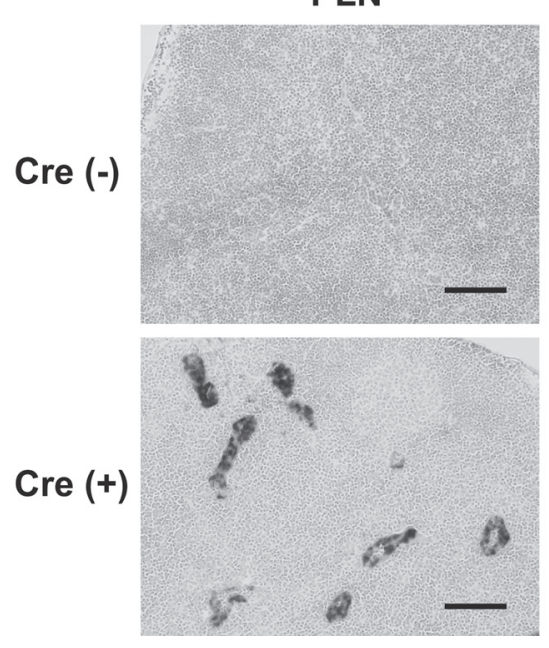

Colon

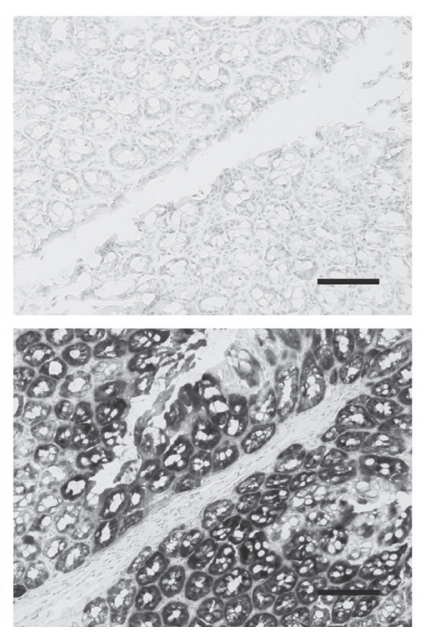

Fig. 4. Generation of GlcNAc6ST-2-Cre transgenic mice. (A) Construction of the recombinant BAC. Into a BAC clone harboring an approximately $220-\mathrm{kb}$ mouse genomic DNA fragment containing the GlcNAc6ST-2 gene was introduced a PCR fragment containing genes encoding Cre recombinase $(\mathrm{Cre})$ and polyA $(p A)$ and the kanamycinresistance gene $\left(K a n^{R}\right)$ flanked by 50-bp DNA fragments (shown by gray boxes) homologous to the GlcNAc6ST-2 gene. $C D S$, coding sequence for GlcNAc6ST-2. Transgenic mice were generated with the recombinant BAC, and one of the founder lines, GlcNAc6ST-2-Cre, was selected for further study. (B) Expression of Cre recombinase in peripheral lymph node (PLN) and colon of GlcNAc6ST-2-Cre transgenic mice. GlcNAc6ST-2-Cre transgenic mice were crossed with the R26R strain (37), which expresses LacZ following recombination in Cre recombinase-expressing cells. Frozen sections of the F1 mice were stained with X-gal. Bars, 100 $\mu \mathrm{m}$. Note that only F1 mice bearing Cre recombinase gene $(\mathrm{Cre}(+))$ were positive for X-gal staining. 


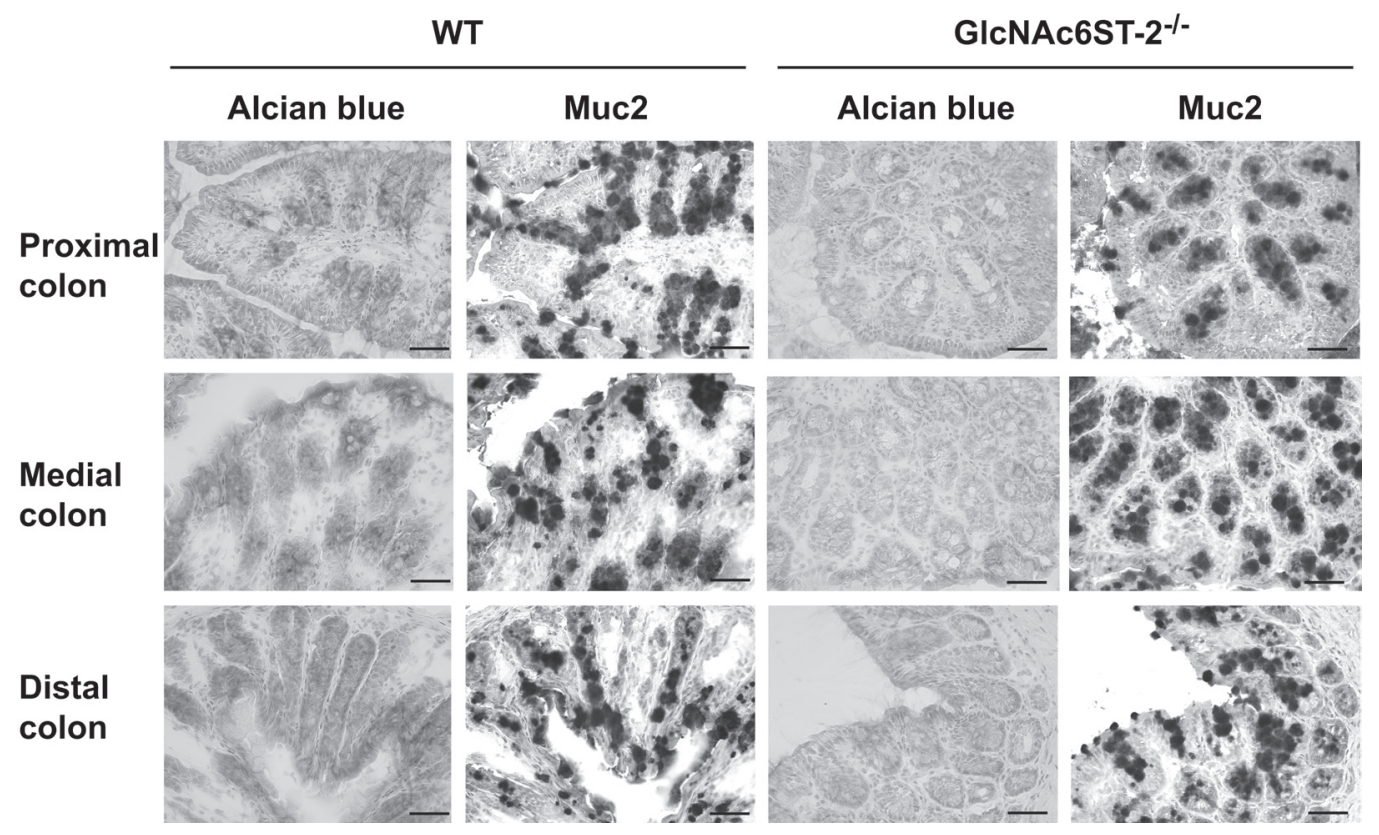

Fig. 5. Expression of sulfated carbohydrates and Muc2 in the colon of wild-type (WT) and GlcNAc6ST-2 $^{-/}$(KO) mice. Frozen sections from WT and KO mice were stained with Alcian blue (pH 1.0), or anti-Muc2 pAb. Bar, $50 \mu \mathrm{m}$.

this condition. In wild-type mice, both Alcian blue and the anti-Muc2 antibody clearly stained colonic epithelial cells, suggesting that the colonic mucins were highly sulfated. In the GlcNAc6ST-2-deficient mice, the Alcian blue staining of the colon was significantly diminished, while the staining intensity with the anti-Muc2 antibody did not differ from that observed in the WT mice. No obvious further reduction of the staining intensity with Alcian blue was observed in the GlcNAc6ST-1 and GlcNAc6ST-2 double-deficient mice, suggesting that GlcNAc6ST-1 is not very involved in the sulfation of colonic mucins, if at all, although its colonic expression in wild-type mice was detected by RT-PCR (19). These results indicate that the sulfation of mucins is largely mediated by GlcNAc6ST-2 in the mouse colon.

\section{F. Structural Analysis of $\boldsymbol{O}$-Glycans Attached to Mouse Colonic Mucins}

We next performed carbohydrate structural analysis of the $O$-glycans of mouse colonic mucins using liquid chromatography coupled to electrospray ionization tandem mass (LC-ESI-MS/MS) spectrometry (19). As shown in Fig. 6A, 15 types of oligosaccharides from the colonic mucinenriched fraction of wild-type mice were detected as their $[\mathrm{M}-\mathrm{H}]^{-}$ions in the LC-ESI-MS analysis. Oligosaccharides containing GlcNAc-6- $O$-sulfate were found on core 2-branched oligosaccharides from wild-type mice at $\mathrm{m} / \mathrm{z} 667,813$, $975 \mathrm{a}$, and 1121. In contrast, these sulfated oligosaccharides were completely absent from the mucin-enriched fraction obtained from the GlcNAc6ST-2-deficient mice (Fig. 6B).
件下で行った。野生型マウスでは、アルシアンブルーおよび 抗 Muc2 抗体はいずれも大腸上皮細胞を明瞭に染色した。こ のことから、大腸ムチンは強く硫酸化されていることが示唆 される。GlcNAc6ST-2 欠損マウスでは、アルシアンブルーに よる染色が顕著に低下したが、抗 Muc2 抗体による染色は野 生型マウスと比べて変化は認められなかった。GlcNAc6ST-1、 GlcNAc6ST-2二重欠損マウスに扔いてもアルシアンブルー 染色の強度がさらに低下するということはなかった。この ことから、野生型マウスに抂いてRT-PCR で大腸における GlcNAc6ST-1 の発現が検出されるにも関わらず (19)、大腸ム チンの硫酸化には GlcNAc6ST-1 はほとんど関与しないと考え られる。以上の結果から、マウス大腸に扔けるムチンの硫酸 化は大部分 GlcNAc6ST-2 によるものであると考えられる。

F. マウス大腸ムチンに付加する $O$ - 型糖鎖の構造解析 次に液体クロマトグラフィー/エレクトロスプレーイオ ン化タンデム質量分析法 (LC-ESI-MS/MS) を用いて、マウス大 腸ムチンの $O$ - 型糖鎖の構造解析を行った (19)。図 6A に示す ように、LC-ESI-MS 解析に扔いて、野生型マウス由来大腸ム チンを濃縮した画分より、15 種類の糖鎖が、 $[\mathrm{M}-\mathrm{H}]^{-}$イオンと して検出された。GlcNAc-6 硫酸を含む糖鎖は野生型マウスの m/z 667, 813, 975a, and 1121 におけるコア 2 分岐型糖鎖に認 められた。一方、これらの硫酸化糖鎖は GlcNAc6ST-2 欠損マ ウスから調製したムチン濃縮画分では完全に欠損していた(図 6B)。次に、これらの硫酸化糖鎖の構造をネガティブイオン 
Fig. 6. LC-ESI-MS analysis of the oligosaccharides on colonic mucins. LC-ESI-MS total ion chromatogram of the oligosaccharides in the mucin-enriched fraction from the colon of wild-type (A) and GlcNAc6ST-2 ${ }^{-/}$(B) mice. LC-ESI-MS was operated in the negative ion mode. The annotations correspond to the $[\mathrm{M}-\mathrm{H}]^{-}$ions listed in Table I.

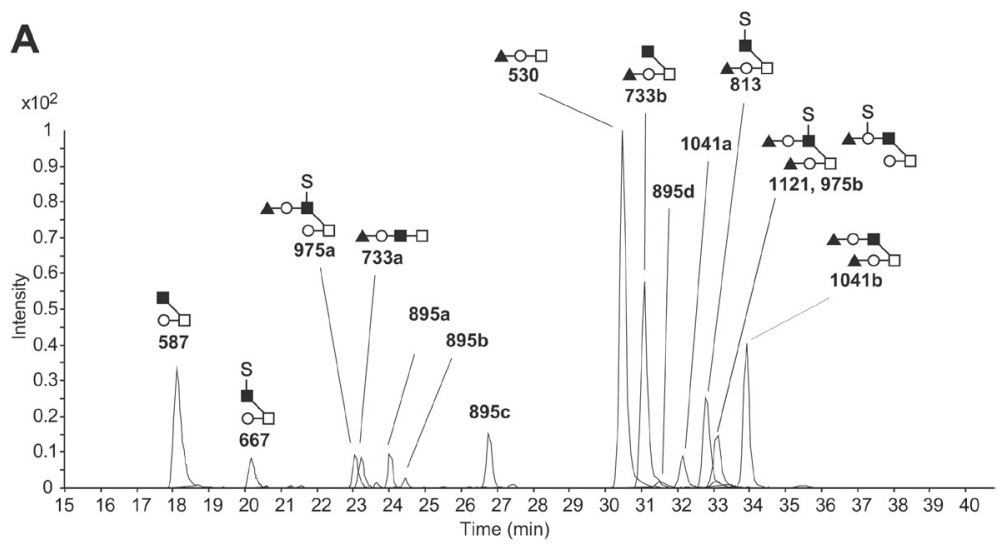

\section{B}

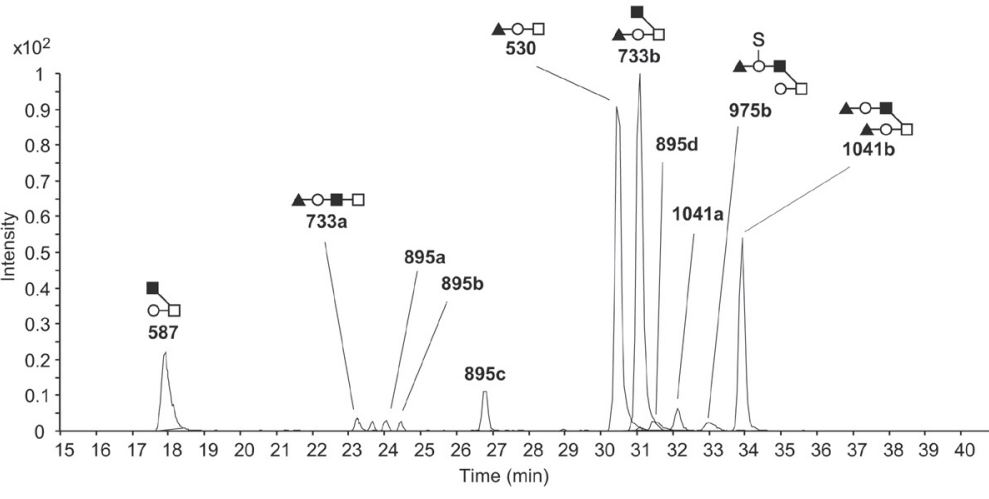

GalNAc GIcNAc $\bigcirc$ Galactose $\triangle$ Fucose $\mathrm{S} \mathrm{SO}_{3}{ }^{-}$
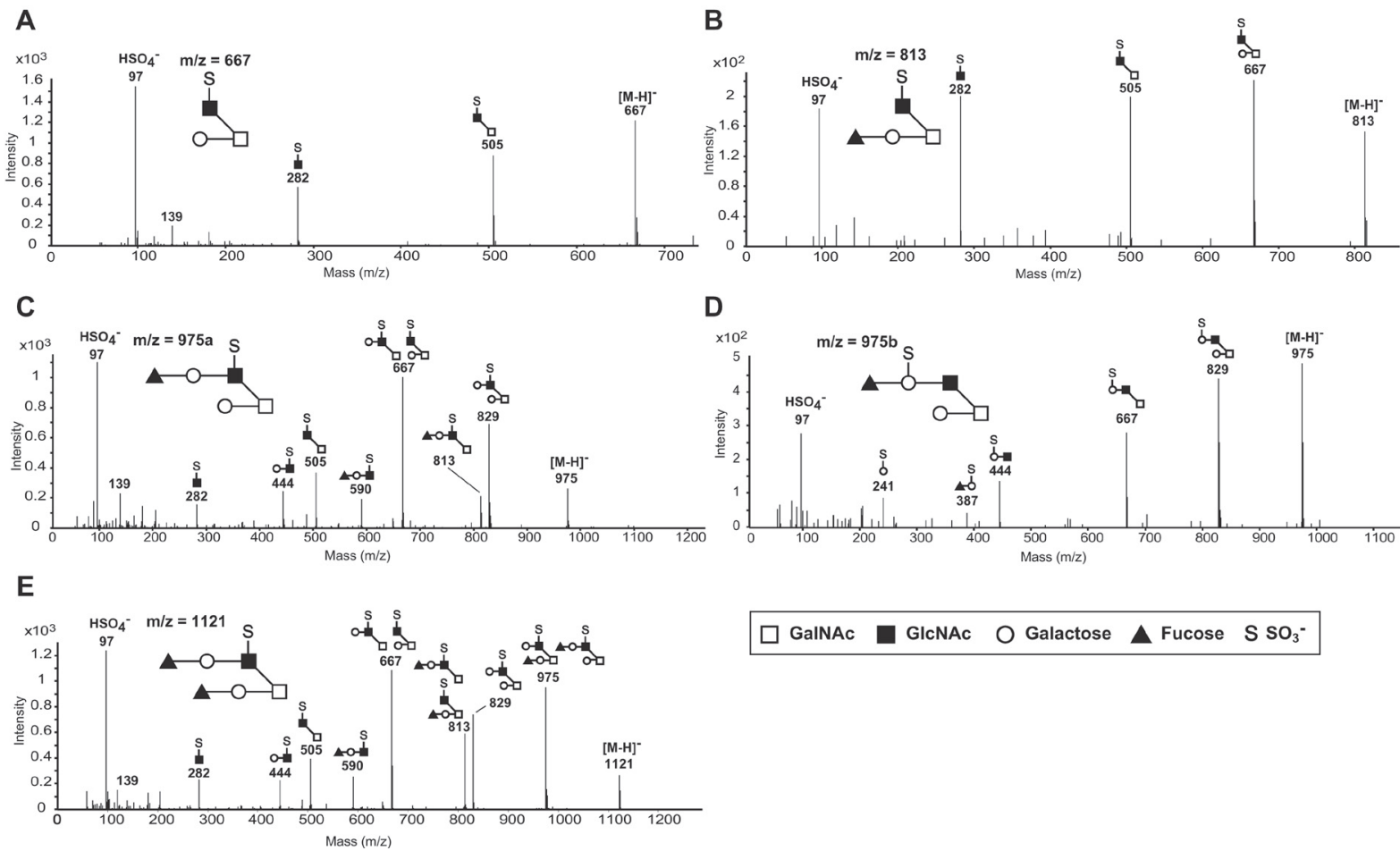

$\square$ GalNAc $\square$ GIcNAc O Galactose $\triangle$ Fucose $\mathrm{S} \mathrm{sO}_{3}{ }^{-}$

Fig. 7. LC-ESI-MS/MS analysis of the sulfated oligosaccharides on colonic mucins. ESI tandem mass spectra of the $[\mathrm{M}-\mathrm{H}]^{-}$ions at $\mathrm{m} / \mathrm{z}, 667$ (A), $\mathrm{m} / \mathrm{z} 813$ (B), $\mathrm{m} / \mathrm{z}$ 975a (C), $\mathrm{m} / \mathrm{z}, 975 \mathrm{~b}$ (D), and $\mathrm{m} / \mathrm{z} 1121$ (E). The collision energies applied were: for $\mathrm{m} / \mathrm{z} 667,50 \mathrm{eV}$; for $\mathrm{m} / \mathrm{z}, 813,60 \mathrm{eV}$; for $\mathrm{m} / \mathrm{z}$.975a, 80eV; for $\mathrm{m} / \mathrm{z}, 975 \mathrm{~b}, 70 \mathrm{eV}$; and for $\mathrm{m} / \mathrm{z}, 1121,90 \mathrm{eV}$. LC-ESI-MS/MS was operated in the negative ion mode. Note the presence of $\mathrm{m} / z, 97\left(\mathrm{HSO}_{4}{ }^{-}\right)$in all the ESI tandem mass spectra. 
Table II. Structural characterization and relative abundance of the $\mathrm{O}$-glycans on the colonic mucins from wild-type (WT) and GIcNAc6ST-2-/- (KO) mice.

\begin{tabular}{|c|c|c|c|}
\hline \multirow[t]{2}{*}{$\begin{array}{l}\text { Molecular ion } \\
{[\mathrm{M}-\mathrm{H}]^{-}}\end{array}$} & \multirow[t]{2}{*}{ Proposed sequence/composition $^{a}$} & \multicolumn{2}{|c|}{$\begin{array}{l}\text { Relative } \\
\text { abundance }(\%)^{b}\end{array}$} \\
\hline & & WT & $\mathrm{KO}$ \\
\hline 587 & Gal-3(GlcNAc-6)GalNAcol & 9.89 & 8.39 \\
\hline 530 & Fuc-Gal-3GalNAcol & 30.43 & 30.50 \\
\hline $733 a$ & Fuc-Gal-GlcNAc-GalNAcol & 2.14 & 1.30 \\
\hline $733 b$ & Fuc-Gal-3(GlcNAc-6)GalNAcol & 18.08 & 34.98 \\
\hline $895 a, 895 b, 895 d$ & Fuc, 2Gal, GlcNAc, GalNAcol & 3.58 & 2.46 \\
\hline $895 \mathrm{c}$ & Gal-3(Gal-(Fuc-)GlcNAc-6)GalNAcol & 3.68 & 3.41 \\
\hline $1041 \mathrm{a}$ & 2Fuc, 2Gal, GlcNAc, GalNAcol & 2.41 & 1.70 \\
\hline $1041 b$ & Fuc-Gal-3(Fuc-Gal-GlcNAc-6)GalNAcol & 10.27 & 16.16 \\
\hline 667 & Gal-3( $\left.\mathrm{SO}_{3}{ }^{-}-6 \mathrm{GlcNAc}-6\right)$ GalNAcol & 2.05 & $-^{c}$ \\
\hline 813 & Fuc-Gal-3( $\left.\mathrm{SO}_{3}{ }^{-}-6 \mathrm{GlcNAc}-6\right)$ GalNAcol & 9.13 & - \\
\hline $975 \mathrm{a}$ & Gal-3(Fuc-Gal-( $\left.\mathrm{SO}_{3}{ }^{-}-6\right)$ GlcNAc-6)GalNAcol & 2.13 & - \\
\hline $975 b$ & Gal-3(Fuc-( $\left.\mathrm{SO}_{3}{ }^{-}-3 / 6\right)$ Gal-GlcNAc-6)GalNAcol & 0.99 & 1.10 \\
\hline 1121 & Fuc-Gal-3(Fuc-Gal-( $\left.\mathrm{SO}_{3}{ }^{-}-6\right)$ GlcNAc-6)GalNAcol & 5.21 & - \\
\hline
\end{tabular}

${ }^{a}$ For structural characterization, the following assumptions were made based on the reported structures of $O$-glycans: The hexose and deoxyhexose are Gal and fucose, respectively, the $\mathrm{N}$-acetylhexosamine residue linked to $\mathrm{N}$-acetylhexosamininitol is GlcNAc linked to GalNAcol, and the core 2 branch is formed after the core 1 structure is formed (40).

${ }^{b}$ The relative abundance was calculated by dividing the area of each peak by the total area of the peaks annotated in Figure 6A and B. Peaks of impurities, which did not produce secondary ions of oligosaccharide fragments in the MS/MS analysis, were excluded from the calculation.

${ }^{c}$ Not detected.

The structures of these sulfated oligosaccharides were characterized by analyzing the daughter ion spectra obtained by the LC-ESI-MS/MS analysis operated at negative ion mode (Fig. 7). Two isomeric sulfated oligosaccharides at $\mathrm{m} / \mathrm{z}$ 975, namely $975 \mathrm{a}$ and $975 \mathrm{~b}$, were found in the LC-ESI-MS/MS analysis. The former oligosaccharide, containing GlcNAc-6-Osulfate, was completely absent in the oligosaccharide fraction from the GlcNAc6ST-2-deficient mice, whereas the latter oligosaccharide, containing Gal-3- or Gal-6- $O$-sulfate, was present in the GlcNAc6ST-2-deficient mice at a comparable level as in the wild-type mice. The neutral oligosaccharides were analyzed by LC-ESI-MS/MS operated at the positive ion mode, since the daughter ions of neutral oligosaccharides were less stable in LC-ESI-MS/MS operated at the negative ion mode. Table II summarizes the carbohydrate structural analysis of the $O$-glycans of the colonic mucins from wildtype and GlcNAc6ST-2-deficient mice. These results indicate that GlcNAc-6-O-sulfation is the predominant sulfate modification of the mouse colonic mucins, and that GlcNAc6ST-2 is essential for this carbohydrate modification.
モードを用いたLC-ESI-MS/MS 分析により各娘イオンを分析 することにより検討した(図 7)。 m/ $/ 2975$ における二つの硫酸 化糖鎖異性体 975a および 975b が LC-ESI-MS/MS 分析により 検出された。GlcNAc-6 硫酸を含む前者の糖鎖は GlcNAc6ST-2 欠損マウス由来の糖鎖画分で完全に欠損していたが、ガラク トース - 3 硫酸またはガラクトース -6 硫酸を含む後者の糖鎖は GlcNAc6ST-2 欠損マウスに扔いて野生型マウスと同程度に検 出された。なお、中性糖鎖はネガティブイオンモードを用い たLC-ESI-MS/MS に打いて安定性が悪かったために、ポジティ ブイオンモードを用いたLC-ESI-MS/MSにより分析した。表 2 に野生型マウス㧍よび GlcNAc6ST-2 欠損マウス由来大腸ム チンの $O$ - 型糖鎖の構造解析の結果をまとめる。これらの結果 は、GlcNAcの 6 位硫酸化はマウス大腸ムチンの主要な硫酸化 であり、この硫酸化には GlcNAc6ST-2 が必須の機能を果たす ことを示している。 


\section{G. Protective Function of Colonic Mucin Sulfation against Experimental Colitis}

Colonic mucins are regarded as a mucosal barrier against infection (20). However, the contribution of the structures of the mucins' carbohydrate moieties to their barrier function is not well known. Muc2 is the most abundant intestinal mucin in the mucus produced by goblet cells (21). Spontaneous colitis, the frequent development of adenomas in the small intestine, and rectal tumors were found in Muc2deficient mice $(22,23)$, indicating the importance of Muc2 as a mucosal barrier. However, only a few reports have shown the consequences of structural changes in the carbohyrdate moiety of Muc2. Core $3 \beta 1,3-N$-acetylglucosaminyltransferase (C3GnT)-deficient mice were highly susceptible to experimental triggers of colitis, which was attributed to a colon-specific reduction in Muc2 protein (24). Core $2 \beta 1$,6$\mathrm{N}$-acetylglucosaminyltransferase-2 (C2GnT2)-deficient mice also showed an increased susceptibility to colitis without a reduction in Muc2 core proteins (25), indicating that the core 2-branched $O$-glycans are required to protect the animal against colitis.

To examine the role of the colonic mucin sulfation by GlcNAc6ST-2 under pathological conditions, we measured the extent of inflammation in dextran sulfate sodium (DSS)induced experimental colitis using GlcNAc6ST-2-deficient mice (19). Seven days after 5\% DSS was administered to wildtype and GlcNAc6ST-2-deficient mice in their drinking water, a significant increase in the $\mathrm{CD} 45^{+}$leukocyte infiltration into the colon was observed in the GlcNAc6ST-2-deficient mice compared with the wild-type mice. Staining of the sections with anti-F4/80 monoclonal antibody ( $\mathrm{mAb}$ ), which is specific for macrophages, and anti-Gr-1 mAb, which is specific for granulocytes, showed that significantly more macrophages and granulocytes infiltrated the proximal colon of the GlcNAc6ST2-deficient mice than that of the wild-type mice. These results indicate that the sulfation of colonic mucins by GlcNAc6ST-2 has a protective function against leukocyte infiltration in experimental colitis in mice.

Recently, it was reported that mice lacking a sulfate transporter, NaS1, showed a decrease in mucin sulfation, accompanied by an enhanced susceptibility to experimental colitis (26). However, the NaS1-deficient mice showed only a partial reduction in mucin sulfation, and no structural data for the $O$-glycans attached to the colonic mucins were reported. On the other hand, the results of our study (19) mentioned above provide evidence that the GlcNAc-6-O-sulfation of colonic mucins was completely eliminated in GlcNAc6ST2-deficient mice, and that this sulfation is important for the barrier function of colonic mucins to prevent the massive leukocyte infiltation induced by DSS administration, indicating a clear relationship between structure and function

\section{G. 実験的大腸炎に対する大腸ムチン硫酸化の防御機能}

大腸ムチンは感染に対抗する粘膜バリアとして機能する と考えられている (20)。しかし、ムチンの糖鎖部分の構造が そのバリア機能にどのように関与するかはよくわかっていな い。Muc2 は杯細胞によって産生される粘液中のもっとも主要 な腸管内のムチンである (21)。Muc2 欠損マウスは、大腸炎を 自然発症するとともに、しばしば小腸腺腫や直腸腫瘍の形成

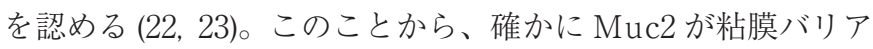
として重要であることがわかる。一方、Muc2 の糖鎖部分の構 造変化がどのような影響を及ぼすかについては $2 \sim 3$ の報告 があるのみである。コア 3 ～1,3- N-アセチルグルコサミン転 移酵素 $(\mathrm{C} 3 \mathrm{GnT})$ 欠損マウスは、実験的な大腸炎誘導因子に感 受性が高く、それはこのマウスで大腸特異的な Muc2 タンパ ク質の産生減少が起こることによるとされている (24)。コア 2 ～1 1,6- $N$ - アセチルグルコサミン転移酵素 - $2(\mathrm{C} 2 \mathrm{GnT} 2)$ 欠損マウ スに拈いては、Muc2 コアタンパク質の減少を伴わずに大腸炎 に感受性が高まることが示されている (25)。このことから、コ ア 2 分岐型 $O$ - 型糖鎖はマウスを大腸炎から防御するために必 要な構造であることがわかる。

病理学的な状況下に抢ける大腸ムチンの GlcNAc6ST-2 に よる硫酸化の役割を調べるために、我々は GlcNAc6ST-2 欠損 マウスを用いてデキストラン硫酸ナトリウム (DSS) 誘発性実験 的大腸炎に扔ける炎症の程度を検討した (19)。野生型マウスお よびGlcNAc6ST-2 欠損マウスに 5\% DSS を飲水中に混ぜて 7 日間投与したところ、GlcNAc6ST-2 欠損マウスにおいて野生 型マウスに比べて有意に多数の CD45 陽性白血球の浸潤の増 加が認められた。マクロファージ特異的な F $4 / 80$ および顆粒 球特異的な Gr-1 に対するモノクローナル抗体による染色の結 果、野生型マウスに比べて GlcNAc6ST-2 欠損マウスに扔いて 有意に多数のマクロファージおよび顆粒球の近位大腸への浸 潤が認められた。これらの結果は、GlcNAc6ST-2による大腸 ムチンの硫酸化は、マウスの実験的大腸炎における白血球浸 潤に対して防御的な役割を果たす事を示すものである。

最近、硫酸トランスポーターNaS1 を欠損するマウスに おいてムチンの硫酸化が低下し、それに伴って実験的大腸 炎に対する感受性が高まることが報告された (26)。しかし、 $\mathrm{NaS1}$ 欠損マウスはムチンの硫酸化が部分的にしか低下して おらず、また大腸ムチンに付加する $O$ - 型糖鎖の構造に関す るデー夕も示されていない。一方、上述の我々の研究結果は GlcNAc6ST-2 欠損マウスに扔いて GlcNAc の 6 位硫酸化が完 全に欠損すること、拉よびこの硫酸化が DSS 投与による大量 の白血球の浸潤から防御するバリア機能にとって重要である ことを示すものであり、マウス大腸ムチンの糖鎖部分の構造 
of the carbohydrate moieties of colonic mucins in mice.

\section{H. Regulation of GIcNAc6ST-2 Expression by Sodium Butyrate}

As mentioned above, the expression of GlcNAc6ST-2 was thought to be specific for the HEVs in lymph nodes. However, our recent study indicated that GlcNAc6ST-2 is also strongly expressed in the mouse colonic epithelium, and that its expression is inhibited by the elimination of commensal bacteria in the colon by antibiotics (9). We thus further examined whether metabolites from commensal bacteria regulate the expression of GlcNAc6ST-2 in the mouse colon (19). We treated a newly established mouse colonic epithelial cell line, CAdC1, with or without the sodium salt of one of the three major short chain fatty acids in the colon: acetate, propionate, or butyrate at the concentration of $4 \mathrm{mM}$ in the presence of EGF. As a result, we found that only sodium butyrate strongly induced the expression of GlcNAc6ST-2 in the presence of EGF. Since sodium butyrate has an inhibitory effect on histone deacetylases (HDACs), the effect of trichostatin A (TSA), an HDAC-specific inhibitor, on the expression of GlcNAc6ST-2 in CAdC1 cells was also examined. TSA also clearly induced GlcNAc6ST-2 mRNA, indicating that the inhibition of HDACs in the presence EGF induces GlcNAc6ST-2 expression. It is reported that the colonic lumen contains total SCFAs at a concentration of 80 to $130 \mathrm{mmol}$ per $\mathrm{kg}$ of total intestinal contents (27). The three major SCFAs, acetate, propionate, and butyrate, constitute about $90 \%$ of the total SCFAs, with a molar ratio of 60:20:20 for acetate:propionate:butyrate (27). Our finding that $4 \mathrm{mM}$ butyrate, which is lower than its physiological concentration, induced the expression of GlcNAc6ST-2 in an immortalized colonic epithelial cell line, suggested that butyrate is involved in GlcNAc6ST-2 expression in vivo. In support of this idea, the administration of sodium butyrate in the drinking water induced the expression of GlcNAc6ST-2 in the small intestines of mice that normally weakly express GlcNAc6ST-2 (19).

Our result indicated that EGF was required for the butyrate-induced expression of GlcNAc6ST-2, suggesting that multiple extracellular signals are required for its gene induction. Since butyrate functions as an HDAC inhibitor and enhances the accessibility of transcription factors to the enhancer/promoter region of various genes by inducing histone acetylation, it is plausible that transcription factors activated by the EGF-EGF receptor pathway are involved in the induction of the gene encoding GlcNAc6ST-2. In humans, it is reported that the normal colon expresses little, if any, GlcNAc6ST-2 $(28,29)$. Since butyrate is produced by commensal bacteria in both human and mouse colon, signals equivalent to those transmitted from the EGF receptor might be lacking in the normal human colon. In this regard,
と機能の関連を明確に示すものである(19)。

H. 酪酸による GlcNAc6ST-2 の発現制御

上述のように、GlcNAc6ST-2 の発現はリンパ節 HEV に特 異的と考えられてきた。しかし、我々の最近の研究結果から GlcNAc6ST-2 がマウス大腸上皮に発現し、その発現は抗生物 質で常在細菌を除去することにより阻害されることがわかっ た (9)。そこで我々はマウス大腸に抢いて腸内細菌の代謝産物 がGlcNAc6ST-2 の発現を制御するかどうかを解析した (19)。 すなわち、新たに樹立したマウス大腸上皮細胞株 CAdC1 に 対して、大腸内の 3 つの主要な短鎖脂肪酸、酢酸・プロピオ ン酸・酪酸のナトリウム塩を $4 \mathrm{mM}$ の濃度で $\mathrm{EGF}$ とともに作 用させた。その結果、酪酸ナトリウムのみが $\mathrm{EGF}$ の存在下で 強くGlcNAc6ST-2 の発現を誘導することを見いだした。酪酸 ナトリウムはヒストンデアセチラーゼ (HDAC) の阻害作用を 持つことから、HDAC 特異的な阻害剤であるトリコスタチン A(TSA) の作用を調べたところ、TSA も GlcNAc6ST-2 mRNA の発現を明らかに誘導した。このことから、EGF 存在下で HDAC を阻害することにより GlcNAc6ST-2 の発現が誘導さ れることが明らかになった。大腸内腔において、大腸の内容 物 $1 \mathrm{~kg}$ 当たりに $80 \sim 130 \mathrm{mmol}$ の濃度の短鎖脂肪酸が含まれ ることが報告されている $(27)$ 。3つの主要な短鎖脂肪酸である 酷酸・プロピオン酸・酪酸は、全短鎖脂肪酸の約 $90 \%$ を占め、 60:20:20 の比で含まれる (27)。生理的濃度以下の $4 \mathrm{mM}$ の酪酸 により不死化大腸上皮細胞株に GlcNAc6ST-2 の発現を誘導す ることができるという我々の研究結果は、生体内に抒いても 酪酸が GlcNAc6ST の発現に関与する可能性を示唆するもので ある。実際に、酪酸ナトリウムを飲水中に加えたところ、通 常は弱くしか GlcNAc6ST-2 を発現しないマウス小腸において GlcNAc6ST-2 の発現が誘導された。

酪酸によるGlcNAc6ST-2 の発現誘導には EGF が必要で あった。このことから、GlcNAc6ST-2 の遺伝子の誘導には複 数の細胞外シグナルが必要であることが示唆される。酪酸は HD AC の阻害剤として働き、ヒストンのアセチル化を誘導し て様々な遺伝子エンハンサー/プロモーター領域への転写因 子の結合を促進することから、GlcNAc6ST-2 をコードする遺 伝子の発現誘導には EGF-EGF レセプター経路によって活性化 される転写因子が関与する可能性が考えられる。ヒトにおい ては正常大腸は GlcNAc6ST-2 をほとんど発現しないことが報 告されている $(28,29)$ 。酪酸はヒト抢よびマウス大腸の常在細 菌のいずれからも産生されることから、正常七ト大腸におい ては EGF レセプターから伝達されるシグナルに相当するもの が欠損している可能性が考えられる。この観点から、ヒト大 腸腺癌 $(28,29)$ が GlcNAc6ST-2 を発現することは注目に值する。 
it is noteworthy that human colon adenocarcinomas express GlcNAc6ST-2 $(28,29)$, since colon adenocarcinomas might be continuously receiving growth signals from the extracellular environment, similar to those transmitted from EGF receptors.

\section{Concluding Remarks}

We have shown that GlcNAc6ST-1 and GlcNAc6ST-2 cooperatively play a major role in the sulfation of mucinlike glycoproteins which function as L-selectin ligands in HEV (7). Mutant mice deficient in both sulfotransferases showed significantly reduced lymphocyte trafficking to PLN, as well as less robust CHS responses after sensitization and challenge with a hapten, DNFB. We also performed a systematic carbohydrate structural analysis of a HEV-derived mucin-like glycoprotein and provided a structural explanation for phenotypes observed in mutant mice. In contrast to the cooperative action of GlcNAc6ST-1 and GlcNAc6ST-2 in $\mathrm{HEV}$, our results indicated that GlcNAc-6-O-sulfation of colonic mucins was exclusively mediated by GlcNAc6ST-2 in the mouse colon, although GlcNAc6ST-1 expression was also detected in the colon by RT-PCR (19). Considering the previous finding that both of these sulfotransferases can transfer sulfate onto core 2-branched $O$-glycans, and our observation that sulfate residues were exclusively present on core 2 branched oligosaccharides of the colonic mucins, the preference for a particular acceptor oligosaccharide structure may not account for the differential activity of GlcNAc6ST-1 and GlcNAc6ST-2 for the colonic mucins. One possible explanation is that the subcellular distribution of GlcNAc6ST-2 is more suitable for transferring sulfate to the GlcNAc-terminated $O$-glycans of colonic mucins, because GlcNAc6ST-1 is confined to the trans-Golgi network, whereas GlcNAc6ST-2 is distributed throughout the Golgi apparatus (30). Another possibility is that differential preferences of GlcNAc6ST-1 and GlcNAc6ST-2 for the Muc2 core protein, a major colonic mucin, accounts for the difference. Indeed, some glycosyltransferases preferentially act on specific core proteins and modulate the functions of such glycoproteins $(31,32)$.

Our carbohydrate structural analysis of mouse colonic mucins described above indicated that the sulfation was preferential on the C-6 of GlcNAc residues of the core2branched $O$-glycans. We also detected a small amount of galactose-sulfated oligosaccharides, consistent with the results of RT-PCR that galactose sulfotransferases, KSST and Gal3STs, were expressed in the mouse colon (19). In contrast to the abundant GlcNAc-6- $O$-sulfation of mouse colonic mucins, most of the sulfation of human MUC2 is found on galactose residues (33). Consistently, the mAb $91.9 \mathrm{H}$, which was raised against human colonic sulfomucin, recognizes the $\mathrm{HSO}_{3}-3 \mathrm{Gal} \beta 1-3$ (Fuc $\left.\alpha 1-4\right)$ GlcNAc structure
なぜなら、それらの腺癌は細胞外環境から常にEGFレセプター からのシグナルに類似した増殖シグナルを受け続けているか もしれないからである。

\section{I. 結 論}

我々は、HEV において GlcNAc6ST-1 と GlcNAc6ST-2 が 協調的に働いて、L-セレクチンリガンドとして働くムチン様 糖タンパク質の硫酸化に主要な役割を果たすことを示してき た (7)。これらの硫酸基転移酵素の両者を欠損する变異マウ スにおいてはPLNへのリンパ球ホーミングが顕著に減少す るとともに、ハプテンである DNFBを用いた感作と惹起に よって引き起こされる接触性皮膚炎が緩和された。また我々 は $\mathrm{HEV}$ 由来のムチン様糖タンパク質の系統的な糖鎖構造解 析を行い、変異マウスにおいて認められた表現型を説明する 構造的基盤を明らかにした。HEVにおけるGlcNAc6ST-1 と GlcNAc6ST-2 の協調的な作用とは対照的に、マウス大腸にお いては、GlcNAc6ST-1 の発現も RT-PCR で検出されるにも関 わらずGlcNAc6ST-2のみが大腸ムチンの GlcNAcの 6 位硫酸 化に関与する事がわかった (19)。これらの硫酸基転移酵素がい ずれもコア 2 分岐 $O$ - 型糖鎖に硫酸を転移できること、および 大腸ムチンのコア 2 分岐糖鎖にのみ硫酸基が付加していたと いう我々の研究結果を考え合わせると、大腸ムチンに対する GlcNAc6ST-1 と GlcNAc6ST-2 の作用の違いは、各酵素の特 定のアクセプター糖鎖に対する好みの違いで説明することは できないように思われる。一つの説明として、GlcNAc6ST-2 の細胞内分布の方が大腸ムチンの $O$ - 型糖鎖の硫酸化により 適している可能性が考えられる。なぜなら、GlcNAc6ST-1 はトランスゴルジネットワークに限局しているのに対して GlcNAc6ST-2 はゴルジ装置全体に広く分布しているからであ る(30)。また、大腸の主要なムチンである Muc2 コアタンパク 質に対する親和性が GlcNAc6ST-1 と GlcNAc6ST-2 で異なる 可能性も考えられる。実際に幾つかの糖転移酵素は、優先的 に特定のコアタンパク質に作用しその機能を調節する事が知 られている $(31,32)$ 。

上述したマウス大腸ムチンの糖鎖構造解析の結果により、 コア 2 分岐型 $O$ - 型糖鎖の GlcNAcの 6 位に優先的に硫酸化 が起こることがわかった。我々は、マウス大腸において RT PCR でガラクトースに硫酸基を転移する KSST および Gal3ST が検出されたことと一致して (19)、ごく少量のガラクトースが 硫酸化された糖鎖も検出した。マウス大腸ムチンにおいては GlcNAc-6 硫酸が豊富に含まれるのに対して、ヒトMUC2 の硫 酸化はほとんどがガラクトース残基に起こる (33)。このことと 一致して、ヒト大腸ムチンに対して樹立されたモノクローナ ル抗体 $91.9 \mathrm{H}$ は $\mathrm{HSO}_{3}-3 \mathrm{Gal} \beta$ 1-3(Fuc $\alpha$ 1-4)GlcNAc 構造を認 識する (34)。興味深いことに、臨床検体においてこのモノクロー 
(34). Interestingly, this mAb binds well to normal epithelial cells in the human colon, but minimally to the adjacent colon carcinoma cells in clinical specimens (35). In addition, studies using rectal biopsies taken at colonoscopy from patients with ulcerative colitis indicated that the sulfation of the mucins is significantly reduced in these patients (36). These clinical data suggest that the sulfation of colonic mucins plays important roles in maintaining the normal physiological function of the colon. In this regard, it is notable that the colonic mucins in both humans and mice are highly sulfated, even though different monosaccharides are preferentially sulfated on the colonic mucins in humans and mice.

In conclusion, our findings demonstrate the essential role of GlcNAc6ST-1 and GlcNAc6ST-2 in the sulfation of mucin-like glycoproteins in HEV, which serves as a dominant ligand for the lymphocyte homing receptor, L-selectin. We also showed that GlcNAc6ST-2 functions as a major sulfotransferase in the sulfation of colonic mucins in mice, which serve as a mucosal barrier against inflammatory stimuli in the intestinal tract. These findings provide new insights into the importance of the structure of the carbohydrate moieties of mucins in health and disease.

\section{J. Acknowledgement}

I would like to thank Drs. Minoru Fukuda (SanfordBurnham Medical Research Institute), and Yasuyuki Imai (University of Shizuoka) for helpful comments. This work was supported in part by Grants-in-Aid for Scientific Research, Category (B) and Grants-in-Aid for Scientific Research on Priority Areas, Dynamics of Extracellular Environments, from the Ministry of Education, Culture, Sports, Science and Technology, Japan (21390023 and 20057022, respectively), and Takeda Science Foundation.
ナル抗体はヒト大腸の正常上皮にはよく結合するが、それと 隣接する大腸癌にはわずかにしか結合しない (35)。また、潰痬 性大腸炎患者より結腸鏡検查により得た直腸の生検材料を用 いた解析により、これらの患者に抏いてはムチンの硫酸化が 顕著に抑制されていることが示されている(36)。これらの臨床 デー夕から、大腸ムチンの硫酸化は大腸の正常な生理機能の 維持に重要な役割を果たすことが示唆される。この観点から、 ヒト抢よびマウスの大腸ムチンは異なる単糖が優先的に硫酸 化されてはいるものの、いずれのムチンも強く硫酸化されて いることは注目に值する。

結論として、我々の研究により GlcNAc6ST-1 および GlcNAc6ST-2 がリンパ球ホーミングレセプター・L- セレクチ ンの主要なリガンドとして機能するムチン様糖タンパク質の 硫酸化に必須の役割を果たすことが明らかになった。また、 GlcNAc6ST-2 は腸管内の炎症性の刺激に対する粘膜バリアと して働くマウス大腸ムチンの硫酸化を担う主要な硫酸基転移 酵素として機能することが示された。これらの研究結果は健 康扔よび病気に扔けるムチンの糖鎖部分の構造の重要性に関 して、新しい視点を提供するものである。

\section{J. 謝 辞}

有益な御助言を賜りました福田穣教授 (Sanford-Burnham Medical Research Institute) 拉よび今井康之教授 (静岡県立大 学)に心より感謝の意を表します。本研究の一部は日本学術振 興会科学研究費補助金・基盤研究 (B) (21390023) 㧍よび文部科 学省科学研究費補助金・特定領域研究 (細胞外環境; 20057022) および武田科学振興財団の援助を受けて行われました。

\section{References}

1. Fukuda, M., Hiraoka, N., Akama, T.O., and Fukuda, M.N. (2001) J. Biol. Chem. 276, 47747-47750.

2. Hemmerich, S., and Rosen, S. D. (2000) Glycobiology 10, 849-856.

3. Bistrup, A., Bhakta, S., Lee, J. K., Belov, Y. Y., Gunn, M.D., Zuo, F. R., Huang, C.C., Kannagi, R., Rosen, S.D., and Hemmerich, S. (1999) J. Cell Biol. 145, 899-910.

4. Hiraoka, N., Petryniak, B., Nakayama, J., Tsuboi, S., Suzuki, M., Yeh, J. C., Izawa, D., Tanaka, T., Miyasaka, M., Lowe, J. B., and Fukuda, M. (1999) Immunity 11, 79-89.

5. Rosen, S.D. (2004) Annu. Rev. Immunol. 22, 129-156.

6. Uchimura, K., Kadomatsu, K., El-Fasakhany, F.M., Singer, M.S., Izawa, M., Kannagi, R., Takeda, N., Rosen, S.D., and Muramatsu, T. (2004) J. Biol. Chem. 279, 35001-35008.

7. Kawashima, H., Petryniak, B., Hiraoka, N., Mitoma, J., Huckaby, V., Nakayama, J., Uchimura, K., Kadomatsu, K., Muramatsu, T., Lowe, J. B., and Fukuda, M. (2005) Nat. Immunol. 6, 1096-1104.

8. Uchimura, K., Gauguet, J.M., Singer, M.S., Tsay, D., Kannagi, R., Muramatsu, T., von Andrian, U.H., and Rosen, S.D. (2005) Nat. Immunol. 6, 1105-1113.

9. Kawashima, H., Hirakawa, J., Tobisawa, Y., Fukuda, M., and Saga, Y. (2009) J. Immunol. 182, 5461-5468.

10. Gallatin, W.M., Weissman, I.L., and Butcher, E.C. (1983) Nature 304, 30-34.

11. von Andrian, U. H., Hasslen, S. R., Nelson, R. D., Erlandsen, S. L., and Butcher, E. C. (1995) Cell 82, 989-999.

12. Yeh, J.C., Hiraoka, N., Petryniak, B., Nakayama, J., Ellies, L. G., Rabuka, D., Hindsgaul, O., Marth, J.D., Lowe, J. B., and Fukuda, M. (2001) Cell 105, 957-969.

13. Rosen, S. D., Singer, M. S., Yednock, T. A., and Stoolman, L. M. (1985) Science 228, 1005-1007.

14. Homeister, J.W., Thall, A.D., Petryniak, B., Maly, P., Rogers, C.E., Smith, P.L., Kelly, R.J., Gersten, K.M., Askari, S.W., Cheng, G., Smith- 
son, G., Marks, R.M., Misra, A.K., Hindsgaul, O., von Andrian, U.H., and Lowe, J.B. (2001) Immunity 15, 115-126.

15. Imai, Y., Lasky, L. A., and Rosen, S. D. (1993) Nature 361, 555-557.

16. Hemmerich, S., Bistrup, A., Singer, M. S., van Zante, A., Lee, J. K., Tsay, D., Peters, M., Carminati, J. L., Brennan, T. J., Carver-Moore, K., Leviten, M., Fuentes, M. E., Ruddle, N. H., and Rosen, S. D. (2001) Immunity 15, 237-247.

17. Hiraoka, N., Kawashima, H., Petryniak, B., Nakayama, J., Mitoma, J., Marth, J.D., Lowe, J.B., and Fukuda, M. (2004) J. Biol. Chem. 279, $3058-3067$.

18. Mitoma, J., Bao, X., Petryanik, B., Schaerli, P., Gauguet, J. M., Yu, S. Y., Kawashima, H., Saito, H., Ohtsubo, K., Marth, J. D., Khoo, K. H., von Andrian, U. H., Lowe, J. B., and Fukuda, M. (2007) Nat. Immunol. 8, 409-418.

19. Tobisawa, Y., Imai, Y., Fukuda, M., and Kawashima, H. (2010) J. Biol. Chem. 285, 6750-6760.

20. Linden, S. K., Sutton, P., Karlsson, N. G., Korolik, V., and McGuckin, M. A. (2008) Mucosal Immunol. 1, $183-197$.

21. Johansson, M. E., Phillipson, M., Petersson, J., Velcich, A., Holm, L., and Hansson, G. C. (2008) Proc. Natl. Acad. Sci. USA 105, 1506415069.

22. Van der Sluis, M., De Koning, B. A., De Bruijn, A. C., Velcich, A., Meijerink, J. P., Van Goudoever, J. B., Buller, H. A., Dekker, J., Van Seuningen, I., Renes, I. B., and Einerhand, A. W. (2006) Gastroenterology 131, 117-129.

23. Velcich, A., Yang, W., Heyer, J., Fragale, A., Nicholas, C., Viani, S., Kucherlapati, R., Lipkin, M., Yang, K., and Augenlicht, L. (2002) Science 295, 1726-1729.

24. An, G., Wei, B., Xia, B., McDaniel, J. M., Ju, T., Cummings, R. D., Braun, J., and Xia, L. (2007) J. Exp. Med. $204,1417-1429$.

25. Stone, E.L., Ismail, M.N., Lee, S.H., Luu, Y., Ramirez, K., Haslam, S.M., Ho, S. B., Dell, A., Fukuda, M., and Marth, J.D. (2009) Mol. Cell. Biol. 29, 3770-3782.

26. Dawson, P. A., Huxley, S., Gardiner, B., Tran, T., McAuley, J. L., Grimmond, S., McGuckin, M. A., and Markovich, D. (2009) Gut 58, 910 -919 .

27. Cummings, J.H., Pomare, E.W., Branch, W.J., Naylor, C.P., and Macfarlane, G.T. (1987) Gut 28, 1221-1227.

28. Seko, A., Nagata, K., Yonezawa, S., and Yamashita, K. (2002) Glycobiology 12, 379-388.

29. Uchimura, K., El-Fasakhany, F.M., Hori, M., Hemmerich, S., Blink, S.E., Kansas, G.S., Kanamori, A., Kumamoto, K., Kannagi, R., and Muramatsu, T. (2002) J. Biol. Chem. 277, 3979-3984.

30. de Graffenried, C. L., and Bertozzi, C. R. (2003) J. Biol. Chem. 278, 40282-40295.

31. Angata, K., Chan, D., Thibault, J., and Fukuda, M. (2004) J. Biol. Chem. 279, 25883-25890.

32. Taniguchi, N., Miyoshi, E., Gu, J., Honke, K., and Matsumoto, A. (2006) Curr. Opin. Struct. Biol. 16, 561-566.

33. Larsson, J.M., Karlsson, H., Sjovall, H., and Hansson, G.C. (2009) Glycobiology 19, 756-766.

34. Tsuiji, H., Hong, J.C., Kim, Y.S., Ikehara, Y., Narimatsu, H., and Irimura, T. (1998) Biochem. Biophys. Res. Commun. $253,374-381$.

35. Irimura, T., Wynn, D. M., Hager, L. G., Cleary, K. R., and Ota, D. M. (1991) Cancer Res. 51, 5728-5735.

36. Raouf, A. H., Tsai, H. H., Parker, N., Hoffman, J., Walker, R. J., and Rhodes, J. M. (1992) Clin. Sci. (London) 83, $623-626$.

37. Soriano, P. (1999) Nat. Genet. 21, 70-71.

38. Akama, T.O., Nishida, K., Nakayama, J., Watanabe, H., Ozaki, K., Nakamura, T., Dota, A., Kawasaki, S., Inoue, Y., Maeda, N., Yamamoto, S., Fujiwara, T., Thonar, E.J., Shimomura, Y., Kinoshita, S., Tanigami, A., and Fukuda, M.N. (2000) Nat. Genet. 26, $237-241$.

39. Bhakta, S., Bartes, A., Bowman, K.G., Kao, W.M., Polsky, I., Lee, J.K., Cook, B.N., Bruehl, R.E., Rosen, S.D., Bertozzi, C.R., and Hemmerich, S. (2000) J. Biol. Chem. 275, 40226-40234.

40. Fukuda, M. (2002) Biochim. Biophys. Acta 1573, 394-405.

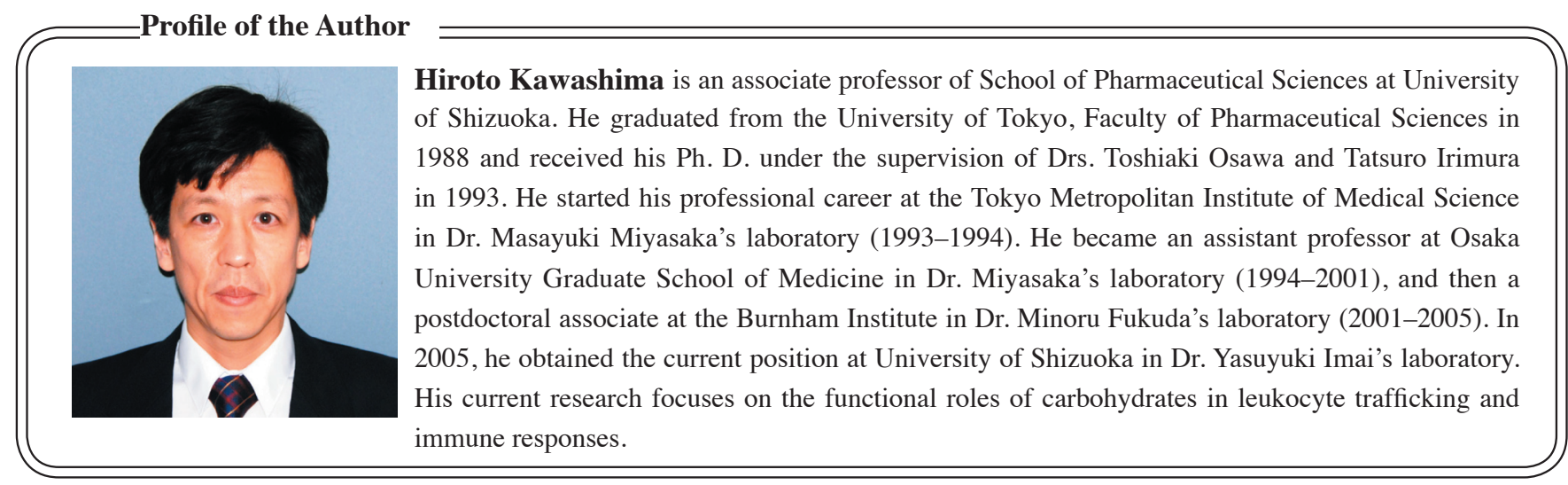

